\title{
Cattle ranchers' attitudes to conflicts with jaguar Panthera onca in the Pantanal of Brazil
}

\author{
A. Zimmermann, M.J. Walpole and N. Leader-Williams
}

\begin{abstract}
Across its range in Latin America the jaguar Panthera onca is threatened by habitat loss and through conflict with people. In the Pantanal of Brazil, where large areas of land are devoted to cattle ranching, jaguars often attack livestock and are persecuted by ranchers. However, the extent to which livestock predation and/or other socio-economic factors affect ranchers' tolerance of jaguars is unclear. This study examined ranchers' attitudes towards jaguars and conservation in the northern Pantanal in order to identify ways of resolving jaguarrancher conflict. The results suggest that most respondents supported the conservation of the Pantanal but that attitudes towards jaguars were mixed and difficult to predict on the basis of socio-economic factors. Attitudes
\end{abstract}

towards jaguars were more closely related to respondents' age and relative wealth than to jaguar-related benefits through tourism or costs through cattle predation. Whilst efforts to reduce cattle losses are needed, it may be equally as important for conservation initiatives to focus on the inherent appreciation of the natural value of the Pantanal within this ranching community.

Keywords Attitudes, conservation strategies, humanwildlife conflict, jaguars, livestock predation, Pantanal, Panthera onca.

This paper contains supplementary material that can only be found online at http:/ /journals.cambridge.org

\section{Introduction}

Wildlife-human conflict is a widespread conservation issue of increasing concern to conservationists (Woodroffe et al., 2005). Livestock is often killed by predators living close to farmland and pastures (Nyhus \& Tilson, 2004; Patterson et al., 2004). Livelihoods can be severely affected by such depredation, generating negative attitudes and persecution of the culprits (Woodroffe \& Ginsberg, 1998; Hussain, 2003).

The extent to which people tolerate wildlife damage may be influenced by various socio-economic factors, including relative wealth, levels of education, the extent to which people derive monetary or other benefit from wildlife, and the magnitude of wildlife-associated costs (Oli et al., 1994; de Boer \& Baquete, 1998). However, personal values also have an important influence on attitudes towards conservation (Naughton-Treves et al.,

\footnotetext{
A. Zimmermann ${ }^{1}$ (Corresponding author), M.J. Walpole ${ }^{2}$ and N. Leader-Williams Durrell Institute of Conservation and Ecology, University of Kent, Canterbury, CT2 7NS, UK.

${ }^{1}$ Current address: Conservation Department, North of England Zoological Society, Zoological Gardens Chester, Chester, CH2 1LH, UK.

E-mail a.zimmermann@chesterzoo.org

${ }^{2}$ Current address: Fauna \& Flora International, Great Eastern House, Tenison Road, Cambridge, CB1 2TT, UK.
}

Received 10 January 2005. Revision requested 21 April 2005. Accepted 7 June 2005
2003). Therefore, understanding which factors influence attitudes and tolerance in different situations is key to choosing and targeting the most appropriate solutions, whether mitigation to reduce losses (Ogada et al., 2003), education to improve awareness (Marker et al., 2003), or benefit generation to provide incentives (Mishra et al., 2003).

In Central and South America conflict between jaguars Panthera onca and cattle ranchers is common and leads to serious livelihood losses and the killing of many jaguars. The jaguar, categorized as Near Threatened (IUCN, 2004), is the third largest cat species and exists in a wide variety of habitats, within and outside protected areas (Nowell \& Jackson, 1996). The jaguar's natural prey base is extremely diverse, with over 85 species recorded in its diet across different parts of its range (Mondolfi \& Hoogesteijn, 1986; Nowell \& Jackson, 1996). Domesticated animals including cattle, horses, donkeys, dogs and pigs also constitute important prey items. Many cattle ranches in South America occupy formerly prime jaguar habitat, and therefore livestock has become easy prey for jaguars in Brazil and Venezuela (Crawshaw \& Quigley, 1991; Hoogesteijn et al., 1993).

Although livestock losses to jaguars have been quantified in a number of sites, there have been few studies of its impact on local attitudes. A recent study by Conforti \& Azevedo (2003) measured attitudes towards jaguars around the 1,700 km² Iguaçu National Park in Brazil. Unlike the Iguaçu region, the $200,000 \mathrm{~km}^{2}$ Pantanal in Brazil is a major stronghold for jaguars globally. The 
Pantanal, however, lacks an extensive network of protected areas, and jaguars must coexist with ranchers on private lands if they are to survive in this economically important region. Therefore, an understanding of the attitudes of the ranchers, who make most decisions about land use in the Pantanal, is vital for the conservation of the global jaguar population. Our study not only explores the attitudes and conservation values of ranchers, but also seeks to disentangle the effects of economic costs and benefits, social factors, and intrinsic values upon such attitudes, placing the results in the context of future jaguar conservation strategies.

\section{Study area}

The Pantanal is the world's largest wetland and spans some $200,000 \mathrm{~km}^{2}$ across the borders of Brazil, Bolivia and Paraguay (Coutinho et al., 1994; Por, 1992; Fig. 1). The region was settled by cattle ranchers over 200 years ago (Wilcox, 1999). The first ranches were many hundreds of thousands of hectares in area, but were later subdivided amongst sons and so the largest of today's ranches are c. 100,000 ha. Nevertheless, c. $98 \%$ of the Pantanal remains privately owned (Gottgens et al., 1998).

The study took place in the northern Pantanal, covering the administrative districts of Cáceres, Poconé and
Barão de Melgaço in the Brazilian state of Mato Grosso. The study area was defined by the federal boundaries of each district, except to the north where the Pantanal biome recedes before the northern limits of Cáceres and Poconé districts. The total area of the three districts within the Pantanal biome is approximately $35,700 \mathrm{~km}^{2}$, comprising c. $26 \%$ of the Brazilian Pantanal. There are two protected areas in the northern Pantanal, Estação Ecológica Taiamã $\left(120 \mathrm{~km}^{2}\right)$ and Parque Nacional do Pantanal $\left(1,400 \mathrm{~km}^{2}\right)$ with its three associated private reserves $\left(530 \mathrm{~km}^{2}\right)$, leaving $33,650 \mathrm{~km}^{2}$ available for ranching. The only road leading into the Pantanal is the $150 \mathrm{~km}$-long Transpantaneira, alongside which are many ranches.

The last status surveys of jaguars in the Pantanal date from the 1980s (Crawshaw \& Quigley, 1991; Quigley \& Crawshaw, 1992). However, ranchers state that jaguars are present in all three districts of the northern Pantanal, although their distribution is patchy. Generally, the highest densities of jaguars occur on both sides of the Paraguay River, in the southern parts of Cáceres and Poconé districts.

\section{Methods}

A structured questionnaire in Portuguese was administered by interview during May-June 2000 to ranchers

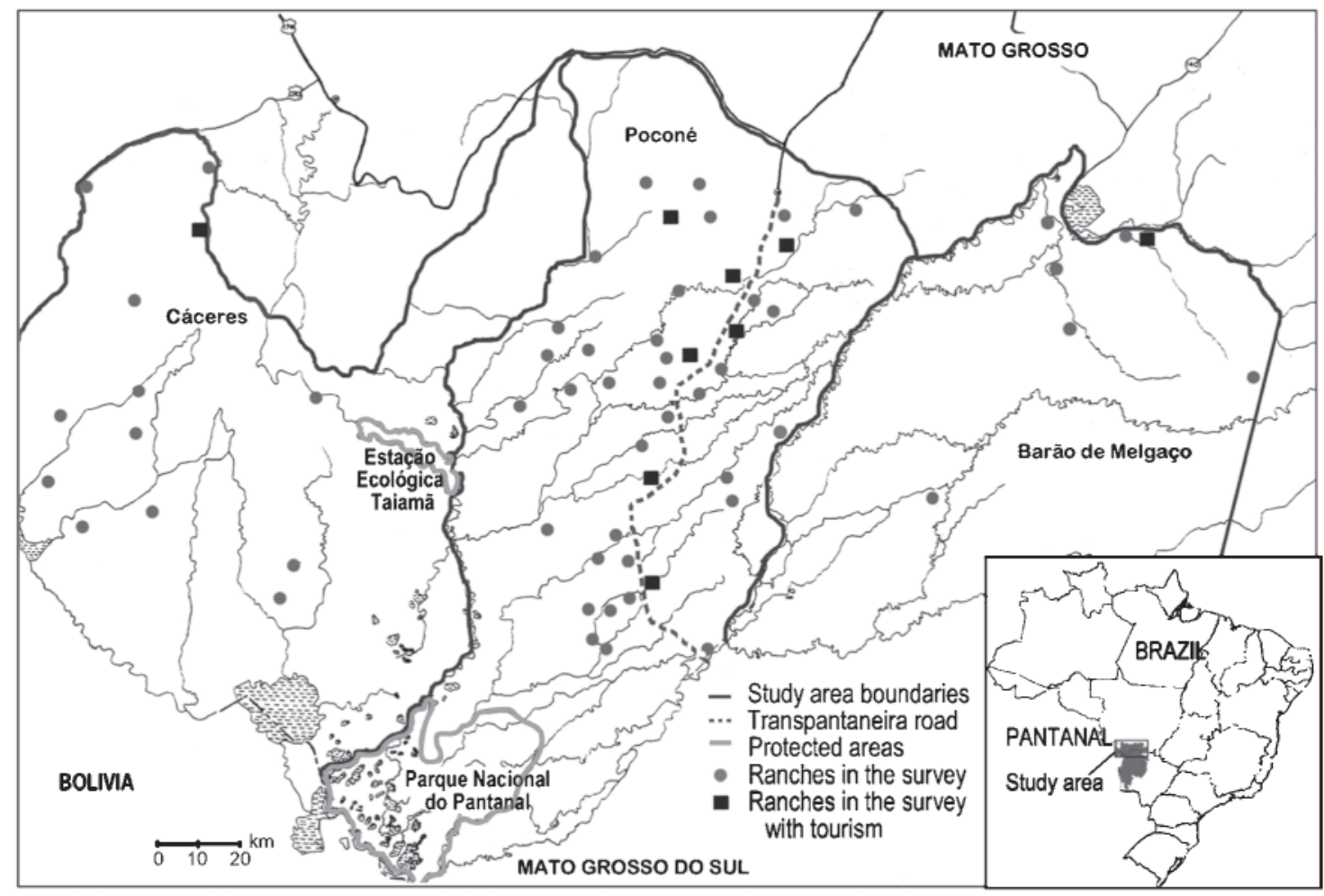

Fig. 1 Map of the study area showing locations of ranches whose owners were interviewed. The inset indicates the location of the study area in Brazil. 
from each district. Some properties near the Transpantaneira could be visited on site but many others were inaccessible overland. Hence, many ranchers were interviewed in their second residences in the nearest towns or at cattle auctions and lasso club events. By interviewing most ranchers away from their ranch, bias towards selecting accessible over inaccessible ranches was reduced. As a result, the ranches of respondents were widely distributed across the study area (Fig. 1).

Following a series of socio-economic questions concerning the age of respondents, the size of ranch, number of cattle, and number of dependents, respondents were asked about their experiences of jaguars, including the number of cattle predated on their ranch in the preceding full calendar year. They were also asked about their involvement in, and the benefits derived from, tourism. Attitudes were explored using a series of suggested statements regarding jaguars and conservation, and responses were recorded on a five-point Likert scale (Appendix).

Analysis was conducted using SPSS v.10 (SPSS Inc., Chicago, USA). Descriptive statistics were derived for all factual and attitudinal questions. Bivariate analyses were conducted between individual attitude statements and potential explanatory variables. Relationships with categorical variables, such as age class and dependence upon tourism, were analysed using the $\chi^{2}$ test. Relationships with continuous variables such as ranch area, number of cattle, cattle density, number of cattle lost to jaguars, and proportion of cattle lost to jaguars, were examined using two-sample $t$-tests. For these and subsequent analyses the explanatory variables were $\log _{10}$ transformed to better approximate a normal distribution.

The answers to six of the jaguar attitude statements were combined into a single additive score (cf. Mehta \& Kellert, 1998; Walpole \& Goodwin, 2001). Answers to each question were coded from zero to four (strongly negative, negative, unsure, positive, strongly positive), and the codes summed to create a combined score from zero to 24 , with higher scores indicating a more positive overall attitude to jaguars. The internal consistency of this combined score was high (Cronbach's alpha $=0.70$ ), suggesting that it was truly additive and reflective of overall attitude. Relationships between the combined score and potential explanatory variables (respondent's age, ranch size, cattle herd size and density, reported cattle losses, and involvement in tourism) were analysed using $t$-tests, analysis of variance and Pearson's correlation coefficient. Multiple stepwise linear regression was used to identify which combination of explanatory variables best predicted the overall attitude score.

\section{Results}

\section{Characteristics of sample}

Fifty respondents completed the questionnaire, most of whom were $41-50$ years old and most $(66 \%)$ had lived at their ranch for 20 years or more. Ranch sizes varied greatly, but the majority (56\%) were $<5,000$ ha in size

Table 1. Summary of all attitude statement results.

\begin{tabular}{|c|c|}
\hline Attitude statement & Agreement rate $(\%)^{*}$ \\
\hline Jaguars are a threat to cattle & 82 \\
\hline Jaguars are a threat to humans & 34 \\
\hline At this ranch we cannot tolerate jaguars taking any cattle & 64 \\
\hline I would be happier if there were no jaguars at all & 40 \\
\hline Jaguars deserve protection & 74 \\
\hline A solution to the problem of jaguar preying on cattle needs to be found & 90 \\
\hline Jaguar predation on cattle is a problem that the local authorities should address & 80 \\
\hline The jaguar problem is for each ranch to solve on its own & 44 \\
\hline $\mathrm{I} /$ we would like to receive help at this ranch in solving the jaguar depredation issue & 94 \\
\hline I benefit directly from tourism & 20 \\
\hline Tourism in the Pantanal is disruptive to my lifestyle and traditions & 20 \\
\hline I am worried about the effects of the construction of the Hidrovia & 42 \\
\hline I am in favour of paving the Transpantaneira & 36 \\
\hline The Pantanal needs more development & 82 \\
\hline The nature/ wildlife of the Pantanal is a national treasure & 100 \\
\hline The nature/ wildlife of the Pantanal is adequately protected & 12 \\
\hline I am worried about the future of the Pantanal's nature/ wildlife & 94 \\
\hline I consider myself aware of conservation problems in the Pantanal & 96 \\
\hline The Pantanal needs more national parks or nature reserves & 46 \\
\hline The existing laws are useful in protecting Pantanal wildlife & 22 \\
\hline I am concerned about overfishing in the Pantanal & 92 \\
\hline I would like to communicate more with conservation scientists and organisations & 86 \\
\hline
\end{tabular}

*\% of respondents who strongly agreed with the statement 
( median $=4,000$ ha, mean $=12,950 \pm$ SE 3,174 ha). The total area of land owned by all respondents combined was 647,504 ha, which covers $19 \%$ of the area available for ranching within the northern Pantanal. The majority $(56 \%)$ of respondents owned 1,000 or less head of cattle (median $=1,000$, mean $=1,980 \pm$ SE 418). There was a positive relationship between log (ranch size) and log (number of cattle) $(r=0.622, \mathrm{P}<0.001)$ but a negative relationship between log (ranch size) and log (cattle density) ( $r=0.512, \mathrm{P}<0.001)$. Most $(82 \%)$ respondents were not presently active in tourism. Those involved in tourism $(n=9)$ had fewer cattle than other ranchers $\left(t_{48}=3.14, \mathrm{P}<0.01\right)$.

\section{Livestock predation by jaguars}

Most (82\%) respondents have suffered cattle losses to jaguars and most $(66 \%)$ believed that jaguar attacks were becoming more common. Most respondents (62\%) reported that jaguar attacks did not show any clear seasonal pattern. Of ranchers claiming to have lost cattle to jaguars in 1999, the average number lost that year was $23 \pm$ SE 4.3 , representing $2.3 \%$ of cattle holdings. There was a positive relationship between cattle lost and both $\log$ (ranch size) and log (number of cattle) $(r=0.413, \mathrm{P}<0.01$, and $r=0.541, \mathrm{P}<0.001$, respectively). However, the proportion of cattle lost declined with increasing ranch size and with cattle numbers $r=-0.590$ and -0.716 , both $\mathrm{P}<0.001)$.

\section{Attitudes towards jaguars and conservation}

Most respondents (82\%) perceived jaguars as a threat to cattle, whereas fewer (34\%) perceived them as a threat to humans. Most (94\%) felt that it was important to solve the problem of cattle predation and wished to receive help with this, while most $(80 \%)$ felt that local authorities should be addressing the issue. More than half (64\%) of respondents could not tolerate jaguars on their ranch, but only $40 \%$ would be happier if there were no jaguars at all. Paradoxically, 74\% felt that jaguars deserve protection. When asked about the extent of losses of cattle to jaguars, 60\% expressed much concern over the issue. From a list of problems that commonly affect ranching, $38 \%$ perceived the jaguar to be of most concern (Fig. 2).

The sensitive issue of whether ranchers still shoot jaguars was explored by asking respondents whether other ranchers in the northern Pantanal killed jaguars to prevent cattle losses. Most respondents (88\%) replied yes, $10 \%$ responded with a more cautious maybe or don't know and $2 \%$ said no.

Ranchers mostly agreed about a number of wider conservation issues. All respondents felt that the Pantanal is a national treasure, and most (94\%) were worried about its future. Most ( $88 \%$ ) felt that the Pantanal is not adequately protected and $78 \%$ believed that existing laws were not sufficient to protect its wildlife. However, respondents were divided in their opinions about whether the Pantanal needs more protected areas (46\% in favour).

\section{Factors influencing attitudes to jaguars}

There were few clear relationships between attitudes towards jaguars and underlying socio-economic factors. Unsurprisingly, those who thought jaguars were a threat to cattle had reported significantly more cattle losses $\left(t_{43}=-3.12, \mathrm{P}<0.01\right)$, as had those that worried about

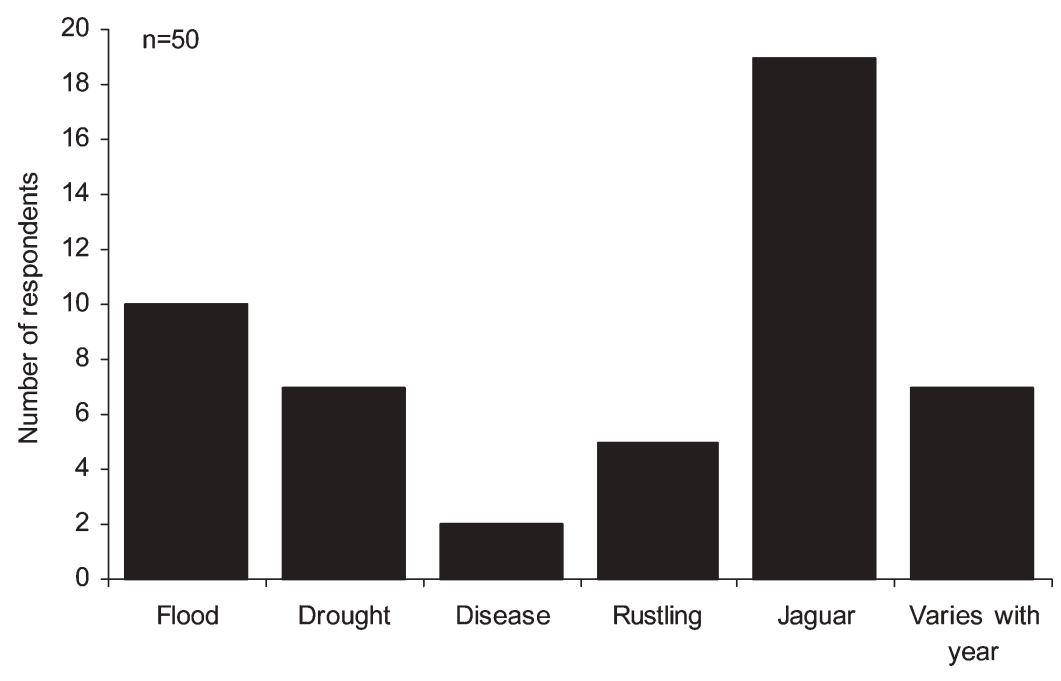

Fig. 2 Respondents' perceptions of the main problems affecting their income from cattle. 
losses $\left(F_{2,42}=-16.7, \mathrm{P}<0.001\right)$. Equally, those who indicated that they could not tolerate jaguars taking cattle on their ranches had lost a marginally higher proportion of their cattle than more tolerant respondents $\left(t_{32}=-1.97\right.$, $\mathrm{P}=0.058)$.

Values for the combined jaguar attitude score ranged from 2 (very negative) to 24 (very positive), with a mean score of $13.4 \pm$ SE 0.68 . There was no significant relationship between the combined attitude score and area of ranch, number of cattle, number or proportion of reported cattle losses, or involvement in tourism. However, there was a weakly significant negative relationship with cattle density $(r=-0.332, \mathrm{P}<0.05$; Fig. 3a). Equally, there was a weak relationship with the age of respondents $\left(F_{5,44}=2.72, \mathrm{P}<0.05\right)$, in that respondents $>60$ years old held more negative views of jaguars than younger respondents (Fig. 3b). Multiple regression did not reveal any combination of variables
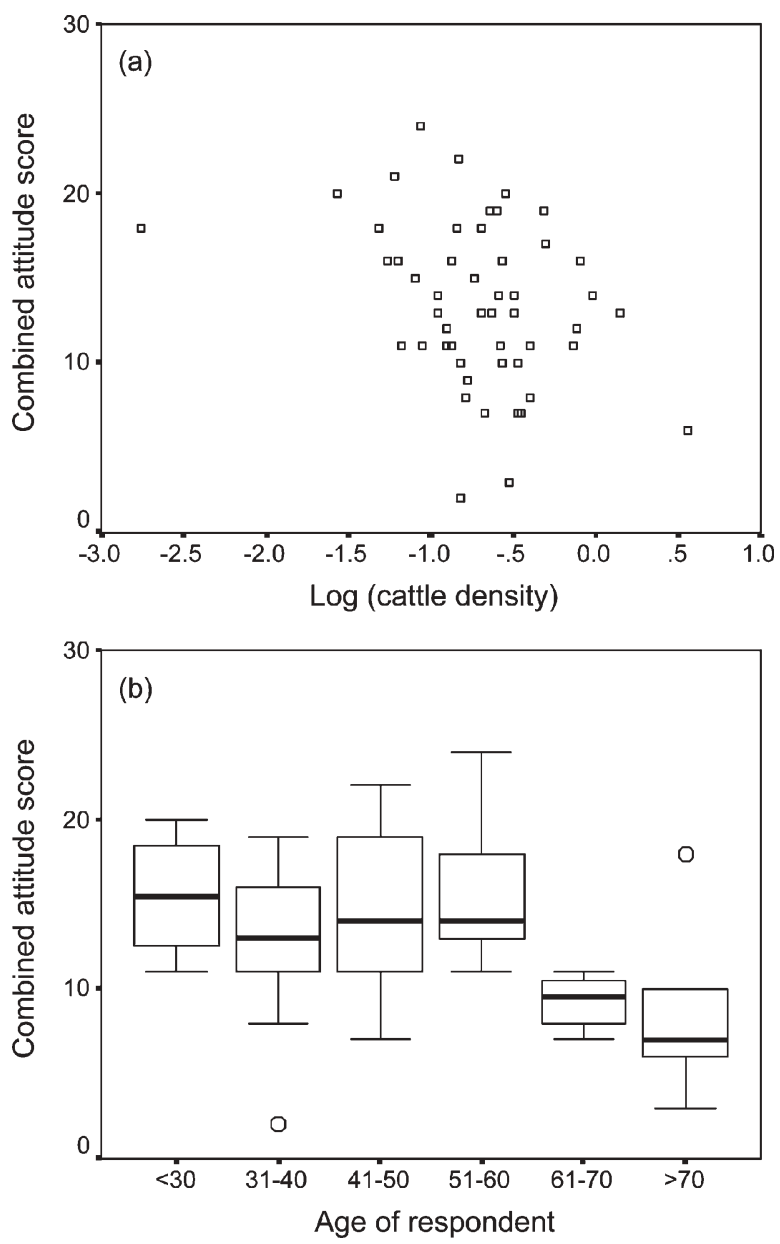

Fig. 3 Relationship between combined attitude scores (see text for details) of each rancher towards jaguars and (a) log cattle density on each ranch, and (b) age of respondent. Open circles in (b) represent outliers. that could better explain the overall pattern of jaguar attitude scores.

\section{Discussion}

\section{Attitudes towards jaguars and conservation}

The results suggest that the ranchers of the northern Pantanal suffer livestock losses that they are mostly not willing to tolerate, and yet they also appreciate the intrinsic natural value of the Pantanal and regard its conservation as important. Ranchers often considered the jaguar to be the most beautiful animal in their environment (survey respondents, pers comm.) but, as reflected by their attitudes, this perception is no guarantee that they will protect it. Their response to the statement 'jaguars deserve protection' was often 'yes, but not on my ranch'. Where ranchers were sympathetic to jaguar conservation, this appeared to originate from personal, pro-conservation attitudes.

Research undertaken across the tropics suggests that wildlife-associated costs reduce tolerance and support for conservation and vice versa (Newmark et al., 1993; de Boer \& Baquete, 1998). Other studies have shown the importance of education and other socio-economic factors (Fiallo \& Jacobson, 1995). The magnitude of livestock predation documented in this study (c. 2-3\%) is not dissimilar to that recorded for other large cats in a range of locations (Oli et al., 1994; Davies \& du Toit, 2004; Patterson et al., 2004). Yet in the northern Pantanal the broad spectrum of attitudes among ranchers does not appear to be heavily affected by socio-economic factors, nor by benefits gained through tourism, nor the costs of cattle predation. In fact, a number of the respondents who held strongly positive attitudes towards conservation and the protection of jaguars suffered extensive cattle losses and did not enjoy supplementary income from conservation.

The ranchers of the Pantanal have high standards of living compared with, for example, subsistence farmers in Africa who also suffer livestock losses to large carnivores. Relatively higher incomes may help to decouple their overall attitudes towards their losses. As a result, attitudes become shaped principally by individual perceptions, beliefs and values, influenced by education, upbringing, tradition, and culture.

\section{Solutions for conservation and conflict resolution}

Although ranchers agreed that the Pantanal needed better protection, opinions over the need for more protected areas were divided. In 1990 the Instituto Brasileiro do Meio Ambiente e dos Recursos Naturais Renovàveis (IBAMA) launched the Reserva Particular do Patrimônio 
Natural scheme to expand Brazil's protected area network through land tax exemption options in return for designating land for conservation purposes (IBAMA, 2000). However, several ranchers commented that they subscribed to the scheme not because of tax savings, which they said were minimal, but because they cared about protecting the Pantanal.

Because law enforcement is logistically difficult in the Pantanal, conservation strategies on privately owned land may still need to rely on voluntary or self-enforcing mechanisms. Therefore, the Pantanal ranchers who are proud of their natural heritage and hold positive attitudes towards conservation are a powerful asset for future conservation planning. Our results suggest that incentive-based approaches (Hutton \& Leader-Williams, 2003) such as tourism may not necessarily be the most important tool for improving or maintaining tolerance and support among Pantanal ranchers towards jaguars. Although benefits of tourism are generally welcomed, they have often been over-promoted as a panacea for conservation. In reality, benefits are limited, communitybased tourism is rarely sustainable (Kiss, 2004) and most ranches are too inaccessible to attract profitable numbers of tourists. Instead, many ranchers expressed interest in trophy hunting as an option to reduce conflict.

Theoretically, a problem of wildlife conflict involving a large cat should lend itself to a strategy of sustainable extractive use, because it is possible for a professional hunter to track down the individual problem animal (Almeida, 1990). This would not only directly solve the rancher's problem and provide an incentive for tolerating losses, but would also address the welfare issue that jaguars are often shot and debilitatingly maimed by ranch workers. Yet if ranchers' views about the protection of jaguars are driven by their individual philosophies towards conserving charismatic species, then there may be no need to place financial value on these animals.

As long as ranchers and their workers perceive jaguars to be a problem, some will continue to persecute them. An alternative approach therefore may be to focus on reducing livestock predation to reduce the costs of conflict. The traditional husbandry practice in the Pantanal, where cattle are left to roam freely, exacerbates the problem. Simple changes to cattle husbandry practices in Venezuela have helped reduce the risk of jaguar depredation (R. Hoogesteijn, pers comm.), and similar techniques have been used to combat large carnivore depredation in Africa (Ogada et al., 2003).

Alongside mitigation methods, our results suggest that any solution to the problem could also include education and raising awareness to maintain positive attitudes and increase tolerance. Such an approach has proved successful in raising the tolerance of cattle ranchers in Namibia towards cheetah, and reducing persecution (Marker et al., 2003). In the case of the Pantanal, it is important to build on the positive baseline of conservation values within the ranching community. For example, one community-based jaguar conflict management programme in the southern Pantanal (Zimmermann, 2003) has already used the insight gained in this study to create a rancher-oriented participatory approach to human-jaguar conflict mitigation.

\section{Acknowledgements}

This study was funded by the North of England Zoological Society and the Durrell Institute of Conservation and Ecology, with air travel provided by British Airways Assisting Conservation. Assistance and information were kindly provided by Fundação Ecotrópica and Associaçao Ecológica Melgassense, Policia Florestal de Varzea Grande and Poconé, Sindicato Rural de Poconé, SEMATUR Cáceres, Angelika Jüncke, Gavur Kirst, Fernando diSerio, Adalberto Eberhardt, Wolf Eberhardt, Eduardo Meirelles, José Augusto Ferraz de Lima, Joaize Lopes, Fenelan Müller, Silvio Araujo, Estelito Rodrigues, Richard Mason, Christina Serrou, Peter Crawshaw, Cheryl Chetkiewicz and the many ranchers who responded to the questionnaire.

\section{References}

Conforti, V.A. \& de Azevedo, F.C.C. (2003) Local perceptions of jaguars (Panthera onca) and pumas (Puma concolor) in the Iguacu National Park area, south Brazil. Biological Conservation, 111, 215-221.

Coutinho, M.E., Mourão, M.G., Pereira Silva, M. \& Campos, Z. (1994) The sustainable use of natural resources and the conservation of the Pantanal wetlands, Brazil. Acta Limnologica Brasiliensia, 5, 165-176.

Crawshaw, P.G. \& Quigley, H.B. (1991) Jaguar spacing, activity and habitat use in a seasonally flooded environment in Brazil. Journal of Zoology, London, 223, 357-370.

Davies, H.T. \& du Toit, J.T. (2004) Anthropogenic factors affecting wild dog Lycaon pictus reintroductions: a case study in Zimbabwe. Oryx, 38, 32-39.

de Almeida, T. (1990) Jaguar Hunting in the Mato Grosso. Safari Press, Long Beach, USA.

De Boer, W.F. \& Baquete, D.S. (1998) Natural resource use, crop damage and attitudes of rural people in the vicinity of the Maputo Elephant Reserve, Mozambique. Environmental Conservation, 25, 208-218.

Fiallo, E.A. \& Jacobson, S.K. (1995) Local communities and protected areas: attitudes of rural residents towards conservation and Machalilla National Park, Ecuador. Environmental Conservation, 22, 241-249.

Gottgens, J.F., Fortney, R.H., Meyer, J., Perry, J.E. \& Rood, B.E. (1998) The case of the Paraguay-Paraná waterway (Hidrovia) and its impact on the Pantanal of Brazil: a summary report to the society of wetland scientists. Wetlands Bulletin, 1998, 12-18. [Also available at http:/ / www.bluemacaws.org/ pantart2.htm, accessed 6 June 2005].

Hoogesteijn, R., Hoogesteijn, A. \& Mondolfi, E. (1993) Jaguar predation and conservation: cattle mortality caused 
by felines on three ranches in the Venezuelan Llanos. In Mammals as Predators (eds N. Dunstone \& M.L. Gorman), pp. 391-407. Symposia of the Zoological Society of London, Clarendon, Oxford, UK.

Hussain, S. (2003) The status of the snow leopard in Pakistan and its conflict with local farmers. Oryx, 37, 26-33.

Hutton, J.M. \& Leader-Williams, N. (2003) Sustainable use and incentive-driven conservation: realigning human and conservation interests. Oryx, 37, 215-226.

IBAMA (2000) Reservas Particulares do Patrimônio Natural. Ampliando os espaços de conservaçao. Instituto Brasilieiro do Meio Ambiente e dos Recursos Naturais Renováveis, Brasilia, Brazil.

IUCN (2004) 2004 IUCN Red List of Threatened Species. IUCN, Gland, Switzerland [http://www.redlist.org, accessed on 1 December 2004].

Kiss, A. (2004) Is community-based ecotourism a good use of biodiversity conservation funds? Trends in Ecology \& Evolution, 19, 232-237.

Marker, L.L., Mills, M.G.L. \& Macdonald, D.W. (2003) Factors influencing perceptions of conflict and tolerance toward cheetahs on Namibian farmlands. Conservation Biology, 17, 1290-1298.

Mehta, J.N. \& Kellert, S.R. (1998) Local attitudes towards community-based conservation policy and programmes in Nepal: a case study of the Makalu-Barun Conservation Area. Environmental Conservation, 25, 320-333.

Mishra, C., Allen, P., McCarthy, T., Madhusudan, M.D., Bayarjargal, A. \& Prins, H.H.T. (2003) The role of incentive programs in conserving the snow leopard. Conservation Biology, 17, 1512-1520.

Mondolfi, E. \& Hoogesteijn, R. (1986) Notes on the biology and status of the jaguar in Venezuela. In Cats of the World, Biology, Conservation and Management (eds S.D. Miller \& D.D. Everett), pp. 85-123. National Wildlife Federation, Washington, DC, USA.

Naughton-Treves, L., Grossberg, R. \& Treves, A. (2003) Paying for tolerance: rural citizens' attitudes toward wolf depredation and compensation. Conservation Biology, 17, 1500-1511.

Newmark, W.D., Leonard, N.L., Sariko, H.I. \& Gamassa, D.G.M. (1993) Conservation attitudes of local people living adjacent to five protected areas in Tanzania. Biological Conservation, 63, 177-183.

Nowell, K. \& Jackson, P. (1996) Wild Cats. Status Survey and Conservation Action Plan. IUCN/SSC Cat Specialist Group, Gland, Switzerland.

Nyhus, P.J. \& Tilson, R. (2004) Characterizing human-tiger conflict in Sumatra, Indonesia: implications for conservation. Oryx, 38, 68-74.

Ogada, M.O., Woodroffe, R., Oguge, N.O. \& Frank, L.G. (2003) Limiting depredation by African carnivores: the role of livestock husbandry. Conservation Biology, 17, 1521-1530.

Oli, M.K., Taylor, I.R. \& Rogers, M.T. (1994) Snow leopard (Panthera uncia) predation on livestock: an assessment of local perceptions in the Annapurna Conservation Area, Nepal. Biological Conservation, 68, 63-68.
Patterson, B.D., Kasiki, S.M., Selempo, E. \& Kays, R.W. (2004) Livestock predation by lions (Panthera leo) and other carnivores on ranches neighboring Tsavo National Parks, Kenya. Biological Conservation, 119, 507-516.

Por, F.D. (1992) The Pantanal of Mato Grosso (Brazil). The World's Largest Wetlands. Kluwer Academic, London, UK.

Quigley, H.B. \& Crawshaw, P.G. (1992) A conservation plan for the jaguar Panthera onca in the Pantanal region of Brazil. Biological Conservation, 61, 149.157.

Walpole, M.J. \& Goodwin, H.J. (2001) Local attitudes towards conservation and tourism around Komodo National Park, Indonesia. Environmental Conservation, 28, 160-166.

Wilcox, R.W. (1999) The law of the least effort - cattle ranching and the environment in the savanna of Mato Grosso, Brazil 1900-1980. Environmental History, 4, 338-368.

Woodroffe, R. \& Ginsberg, J.R. (1998) Edge effects and the extinction of populations inside protected areas. Science, 280, 2126-2128.

Woodroffe, R., Thirgood, S. \& Rabinowitz, A. (2005) People and Wildlife: Conflict and Coexistence. Cambridge University Press, Cambridge, UK.

Zimmermann, A. (2003) Rancher Outreach Program, Brazil. WCS International Conservation. Http:/ / savethejaguar.com/ media/file/zimmermann1.pdf [accessed 10 May 2005].

\section{Appendix}

The appendix for this article is available online at http: / / journals.cambridge.org

\section{Biographical sketches}

Alexandra Zimmermann is interested in human-wildlife conflict, particularly how culture and social psychology influence relationships with wildlife. She has led a community-based jaguar conflict management programme in Brazil for the Wildlife Conservation Society, and currently coordinates field conservation programmes for Chester Zoo, including an elephant conflict mitigation project in India.

Matt Walpole was at the Durrell Institute of Conservation and Ecology (DICE) for 10 years, specializing in multidisciplinary approaches to conservation, including humanwildlife conflict mitigation and the role of ecotourism as a conservation and development tool. He recently moved to Fauna \& Flora International where he coordinates a global project exploring the links between livelihoods and conservation.

Nigel Leader-Williams' interests include sustainable use, law enforcement and community-based conservation. He has studied introduced reindeer on South Georgia and black rhinos in Zambia, and has advised the government of Tanzania on wildlife policy. He is currently Professor of Biodiversity Management at DICE. 